Penelitian

\title{
Imunohistokimia Patogenitas Viral Nervous Necrosis Isolat Lapang Bali yang Diinfeksikan pada Kerapu Macan Budidaya
}

\author{
(Imunohistochemistry of Pathogenicity Viral Nervous Necrosis Bali Field Isolate are Infected in Tiger \\ Grouper Marine Culture)
}

Putu Eka Sudaryatma ${ }^{*}$, Artanti Tri Lestari ${ }^{1}$

1) Laboratorium Uji Balai Karantina Ikan Pengendalian Mutu dan Keamanan Hasil Perikanan kelas I Denpasar *Penulis untuk korespondensi: putuekasudaryatma@yahoo.com

Diterima 22 Januari 2014, Disetujui 21 Juni 2014

\begin{abstract}
ABSTRAK
Di Indonesia dilaporkan bahwa VNN (Viral Nervous Necrosis) telah menyerang sebagian besar budidaya ikan kerapu dengan tingkat kematian 100\%. Untuk mencegah penyebaran penyakit VNN pada kerapu yang dilalulintaskan Balai Karantina Ikan Pengendalian Mutu dan Keamanan Hasil Perikanan kelas I Denpasar mengembangkan pemeriksaan imunohistokimia untuk mengetahui tingkat patogenitas VNN sebagai dasar penanggulangan dan pencegahan penyakit VNN di wilayah Bali. Kerapu macan berukuran $150 \mathrm{~g}$ - $300 \mathrm{~g}$ sebanyak 50 ekor diaklimatisasi, sepuluh ekor kerapu sebagai kontrol, 40 ekor diinjeksi dengan inokulum VNN (isolat Bali) konsentrasi 10,5 yang dipelihara tanpa siklus pergantian air. Pengamatan gejala klinis dan pengambilan sampel organ dilakukan 12 jam pasca infeksi dan berturutturut setiap $12 \mathrm{jam}$. Pengambilan organ digunakan untuk pemeriksaan imunohistokimia (streptavidinbiotin) dan uji konfirmasi menggunakan pemeriksaa RT- PCR kit IQ-200o VNN. Hasil imunohistokimia pada 24 jam pertama hanya menyerang mata dan otak, 36 jam pasca infeksi virus penyebab VNN terdapat di organ jantung, 48 jam pasca infeksi virus penyebab VNN terdapat di organ hati dan limpa yang diakhiri pada 60 jam pasca infeksi virus penyebab VNN berada di organ ginjal. Distribusi VNN yang luas pada seluruh organ tubuh menunjukkan bahwa viraemia menjadi faktor penting dalam patogenesis infeksi penyakit VNN.
\end{abstract}

Kata kunci: VNN, patogenitas, kerapu macan, imunohistokimia

\begin{abstract}
In Indonesia was reported VNN (Viral Nervous Necrosis) has invaded most of grouper culture with a mortality rate of $100 \%$. To prevent the spread of VNN in groupers export from Balai Karantina Ikan Pengendalian Mutu dan Keamanan Hasil Perikanan kelas I Denpasar, it develop immunohistochemistry to determine the level of pathogenicity VNN as a basis for prevention and disease prevention VNN in Bali. Tiger grouper sized 150 - $300 \mathrm{~g}$ as much as 50 animals acclimatized, ten head of grouper as a control, 40 tails were injected with an inoculum concentration of $10^{1.5} \mathrm{VNN}$ are preserved without change of the water cycle. Observation of clinical symptoms and organ sampling performed 12 hours post-infection and successively every 12 hours, making the organ used for immunohistochemistry (streptavidin-biotin) and a confirmatory test using RT - PCR kit examination of the IQ -2000 VNN. Immunohistochemical results on the first 24 hours only attacks the eyes and brain, 36 hours post-infection the virus that was found in cardiac, 48 hours post-infection the virus that VNN contained in the liver and spleen were terminated at 57 hours post-infection the virus in the kidney. Spread of VNN distribution in all organs showed that viraemia is an important factor in the pathogenesis of infectious diseases VNN.
\end{abstract}

Keywords: VNN, immunohistochemistry, tiger grouper, patogenitas 


\section{PENDAHULUAN}

Di Indonesia dilaporkan bahwa VNN (Viral Nervous Necrosis) telah menyerang sebagian besar budidaya ikan kerapu dengan tingkat kematian $100 \%$. Penyakit VNN merupakan masalah serius pada budidaya ikan laut terutama kerapu dan kakap karena dapat menyebabkan kematian 50-100\% pada larva umur 10-20 hari (Koesharyani et al., 1999). Sedangkan pada ikan ukuran 2-5 cm kematian sampai 100 $\%$, serta kematian kurang $<20 \%$ pada ikan ukuran $>15 \mathrm{~cm}$ (Gilda et al., 2009). Virus penyebab VNN umumnya menginfeksi stadia larva sampai juvenil dan menyerang sistem syaraf mata dan otak yang ditandai dengan adanya vakuolasi, dengan gejala yang cukup spesifik karena ikan menunjukkan tingkah laku berenang yang tidak normal dan diam di dasar bak (Yuasa et al., 2001).

Gejala yang ditimbulkan adalah dengan ikan berputar-putar atau whirling, terjadi sleeping dead atau ikan berada di dasar seperti mati serta adanya gejala tingkah laku yang tidak wajar (Yuasa et al., 2000). Viral Nervous Necrosis ini umumnya menyerang sistem organ syaraf mata dan otak yang dapat menyebabkan kelainan pada ikan yang diserang. Yuasa et al. (2001) menjelaskan bahwa VNN umumnya menginfeksi stadia larva sampai yuwana dan menyerang sistem organ syaraf mata dan otak dengan gejala yang cukup spesifik karena ikan menampakkan tingkah laku berenang yang tidak normal dan umumnya ikan berdiam di dasar.

Untuk mencegah penyebaran penyakit VNN pada kerapu yang dilalulintaskan dari Bali maka Balai Karantina Ikan Pengendalian Mutu dan Keamanan Hasil Perikanan kelas I Denpasar sebagai salah satu pintu keluar komoditas ekspor berusaha mencegah penyebaran penyakit VNN pada kerapu macan. Menurut OIE (2006) deteksi VNN yang disarankan adalah dengan menggunakan tehnik reverse transcript PCR (RT-PCR), indirect fluorescent antibody technique (IFAT), enzyme linked immuno assay (ELISA) dan imunohistokimia/imunositokimia. Oleh karena itu, Laboratorium Uji Balai Karantina Ikan Pengendalian Mutu dan Keamanan Hasil Perikanan kelas I Denpasar mengembangkan pemeriksaan imunohistokimia untuk mengetahui tingkat patogenitas ikan kerapu yang dibudidayakan, sehingga hasil dari penelitian ini dapat digunakan sebagai dasar penanggulangan dan pencegahan penyakit VNN di wilayah kerja Balai Karantina Ikan Pengendalian Mutu dan Keamanan Hasil Perikanan kelas I Denpasar.

\section{BAHAN DAN METODE}

Bahan yang digunakan dalam uji coba yaitu kerapu macan (Epinephelus fuscoguttatus) dengan ukuran berat 150-300 g berjumlah 50 ekor; pakan ikan kerapu. Bahan imunohistokimia menggunakan akuades, alkohol absolut, neutral buffered formalin (NBF) 10\%, parafin, pewarna hematoksilin, phospate buffered saline (PBS), metanol absolut, entelan, kit imunokimia menggunakan ultravision detection system (Anti-Polyvalent, HRP-DAB) dari Thermo scientific, antibodi poliklonal VNN menggunakan Anti-Fish Nervous Necrosis Virus Particles (RabbitPolyclonal Antibody) dari Genesis Biotech Inc., pewarna hematoksilin, entelen. Bahan pemeriksaan RT-PCR VNN menggunakan kit IQ-2000, klorofom, isopropanol, alkohol $75 \%$ dan $95 \%$, bahan-bahan amplifikasi, nuclease free water, agarose, TAE buffer, ethidium bromida, distilled water, kertas gel doc print.

Alat yang digunakan adalah bak ikan, ember, seser, termometer, refraktometer, sarung tangan, masker, papan bedah, mortar, tissue processor, tissue embbed, microtome, stainning glass block, dissecting set, glass ware, micropipet, microtube 0,2 dan 1,5 ml, microtip, spuit ukuran 1-5 ml, object glass, cover glass, pipet, analitical balance, hot plate, vortex mixer, thermal blok, patsel dan glass ware, rak microtube, deep freezer, freezer, thermalcycler, elektroforesis dan UV Trans-illuminator.

Koleksi inokulum penyebab VNN yang dimiliki oleh Balai Karantina Ikan, Pengendalian Mutu dan Keamanan Hasil Perikanan kelas I Denpasar didapat dari ikan kerapu budidaya di wilayah Bali Utara pada tahun 2010 yang mengalami wabah VNN, kemudian organ mata dan otak ikan kerapu dibuat inokulum dengan konsentrasi 9,25 × 10² $\mu \mathrm{g} / \mathrm{ml}$. Konsentrasi partikel VNN diencerkan menjadi $10^{1,5} \mu \mathrm{g} /$ $\mathrm{ml}$ kemudian disuntikkan $100 \mu \mathrm{l}$ setiap ikan. Menurut Kokawa et al. (2008), LD 50 inokulum homogen otak mengandung $10^{1,5} \mathrm{LD}_{50} / 100 \mu \mathrm{l}$.

Kerapu macan berukuran 150 - 300 g diaklimatisasi selama lima hari untuk mengetahui status dan tingkat kesehatan kerapu macan. Sepuluh ekor kerapu digunakan sebagai kontrol, harus memiliki hasil negatif VNN dengan RT-PCR dan imunohistokimia. Kemudian, 40 ekor kerapu macan diinjeksi dengan inokulum VNN sebanyak $100 \mu$ l pada setiap ikan, diawali dengan mengusap kapas beralkohol $70 \%$ pada permukaan ikan sebelum dan sesudah injeksi. Pemeliharaan ikan yang diinjeksi inokulum virus penyebab VNN dilakukan pada empat bak yang berbeda tanpa siklus pergantian air selama sepuluh hari. Pengamatan gejala klinis ikan dan pengam- 
bilan sampel organ dilakukan 12 jam pasca infeksi dan berturut-turut setiap 12 jam berikutnya. Ikan yang menunjukkan gejala klinis virus penyebab VNN dan atau kondisi sekarat langsung dilakukan pengamatan makroskopis dan pengambilan organ (mata, otak, hati, jantung, limpa dan ginjal) untuk dilakukan pemeriksaan imunohistokimia dan uji konfirmasi menggunakan pemeriksaa RT- PCR.

Organ yang didapat kemudian dibagi menjadi dua jenis fiksasi, bagian organ pertama difiksasi menggunakan NBF 10\% selama 24-36 jam untuk pemeriksaan imunohistokimia dan bagian kedua difiksasi dengan alkohol 95\% untuk pengujian RT-PCR. Organ yang difiksasi dengan NBF 10\% dilanjutkan dengan tissue processing bertingkat (alkohol 70\%, 80\%, 90\%, 95\% dan parafin). Parafin blok yang didapatkan langsung dilakukan pemotongan pita jaringan yang direkatkan pada objek gelas. Selanjutnya dilakukan deparafinisasi dan rehidrasi yang dilanjutkan dengan pewarnaan imunohistokimia streptavidin biotin dengan tahapan seperti yang tercantum pada petunjuk cara pewaranaanya pada perangkat diagnosis streptavidin biotin dengan menggunakan counter stain hemotoksilin. Setelah selesai tahap clearing pada pewarnaan, preparat ditetesi dengan bahan perekat entelan, ditutup dengan cover glass dan dikeringkan kemudian diamati dibawah mikroskop cahaya. Hasil positif preparat organ setelah diwarnai akan ditemukan berwarna coklat keemasan pada organ. Organ yang difiksasi dengan etanol 95\% dihomogenkan diambil masing-masing sebanyak $15 \mu$ untuk dilakukan uji konfirmasi sesuai dengan metode kerja OIE kit IQ-2000 pemeriksaan VNN, hasil dari PCR didokumentasikan di kertas gel-doc dan difoto menggunakan kamera.

Analisa hasil dilakukan secara deskriptif dari hasil pengamatan gejala klinis, pengamatan mikroskopis imunohistokimia organ dengan membandingkannya menggunakan uji konfirmasi RT-PCR.

\section{HASIL}

Kerapu macan yang dipelihara menunjukkan perubahan gejala klinis dan lesi patologi anatomi setelah diinfeksi virus prnyebab VNN. Perubahan gejala klinis ikan kerapu macan dimulai dengan berenang miring, berenang terbalik, inkoordinasi gerakan berenang sampai dengan ikan berwarna lebih gelap (Tabel 1).

Tabel 1 Pengamatan gejala klinis dan lesi patologi anatomi ikan pasca injeksi

\begin{tabular}{|c|c|c|}
\hline $\begin{array}{c}\text { Waktu } \\
\text { (pasca injeksi) }\end{array}$ & Gejala klinis & Lesi patologi anatomi \\
\hline 12 jam & Berenang normal, gesit. & insang geripis, tubuh menggelap. \\
\hline 24 jam & $\begin{array}{l}\text { Sudah ada ikan yg berenang } \\
\text { dipermukaan, berenang miring tapi } \\
\text { masih gesit. }\end{array}$ & $\begin{array}{l}\text { Sirip ekor geripis, mulut bawah luka, insang pucat, hati } \\
\text { merah kuning, perut kembung, limpa bengkak. }\end{array}$ \\
\hline 36 jam & $\begin{array}{l}\text { Ikan yg berenang dipermukaan, } \\
\text { berenang miring dan warna tubuh } \\
\text { menggelap. }\end{array}$ & $\begin{array}{l}\text { Sirip ekor geripis, mulut bawahluka, tubuh menggelap, } \\
\text { limpa bengkak dan bercak-bercak merah, hati } \\
\text { menguning. }\end{array}$ \\
\hline 48 jam & $\begin{array}{l}\text { Ikan berenang dipermukaan, berenang } \\
\text { terbalik, warna tubuh menggelap dan } \\
\text { perut tampak membesar. }\end{array}$ & $\begin{array}{l}\text { Luka di mulut, merah di sirip dada, sirip ekor geripis, } \\
\text { limpa bengkak, hati menguning, dilatasi gelembung } \\
\text { renang, }\end{array}$ \\
\hline 60 jam & $\begin{array}{l}\text { Ikan sekarat, tidak ada refleks dan } \\
\text { sudah ada ikan yg mati. }\end{array}$ & $\begin{array}{l}\text { Sirip ekor geripis, mulut luka, hati rapuh dan kuning, } \\
\text { dilatasi gelembung renang, limpa bengkak dan ginjal } \\
\text { bengkak. }\end{array}$ \\
\hline
\end{tabular}

Lesi patologi anatomi tampak pada awal 24 jam seperti mulut bagian bawah mulai luka, insang berwarna merah kepucatan kemudian diikuti berturut-turut 12 jam seperti hati mulai berwarna merah pucat sampai merah kekuningan disertai dengan limpa bengkak. Hasil imunohistokimia pada jaringan kerapu macan menunjukkan hasil positif VNN pada jaringan mata, otak, jantung, hati, limpa serta ginjal yang dapat dilihat pada Tabel 2. 
Tabel 2 Hasil pengamatan imunohistokimia pada organ setelah diinfeksi

\begin{tabular}{ccccccc}
\hline Waktu & \multicolumn{7}{c}{ Organ } \\
\cline { 2 - 7 } Pengamatan & Mata & Otak & Jantung & Hati & limpa & Ginjal \\
\hline 24 jam & $v$ & $v$ & - & - & - & - \\
36 jam & $v$ & $v$ & $v$ & - & - & - \\
48 jam & $v$ & $v$ & $v$ & $v$ & $v$ & \\
60 jam & $v$ & $v$ & $v$ & $v$ & $v$ & $v$ \\
\hline
\end{tabular}

Keterangan:

$\checkmark$ : Ditemukan warna coklat keemasan pada sel/jaringan

- : Tidak ditemukan warna coklat keemasan pada sel/jaringan

\section{PEMBAHASAN}

\section{Pengamatan Gejala Klinis}

Gejala klinis kerapu macan pada awal pengamatan 12 jam menunjukkan gerakan renang yang masih normal dan gesit. Ikan banyak bergerombol di dasar bak yang masih menunjukkan gejala yang normal seperti yang diungkapkan oleh Antoro et al., (2004) bahwa kerapu sehat selalu menggerombol dan diam di dasar bak, karena ikan kerapu merupakan tipe ikan karang yang senang berada di dasar laut. Pengamatan 24-36 jam kemudian, kerapu macan menunjukkan gerakan berenang di permukaan dan warna tubuh yang mulai menggelap tetapi bila diberi gerak reflek ikan masih memberikan perlawanan yang gesit.

Gerakan renang ikan mulai menurun setelah 48 jam kemudian, ikan banyak berenang di permukaan dan berenang vertikal, ini menunjukkan bahwa ikan sudah mulai kehilangan keseimbangan. Warna ikan menjadi gelap atau pucat menunjukkan bahwa ikan mengalami stres. Yoshikoshi \& Inoue (1990) mengatakan bahwa ikan yang terinfeksi virus penyebab VNN akan mengalami perubahan gerakan berenang dan warna tubuh yang menggelap dan berenang berputar di permukaan. Dari gejala klinis dapat dilihat ikan banyak mengalami luka pada mulut dan sirip yang geripis, perubahan gerakan renang tampak sangat jelas dengan adanya luka di bagian bawah mulut, keadaan ini menandakan bahwa ikan mulai kehilangan keseimbangan dalam berenang sehingga sering menabrakkan diri ke dinding dan/atau dasar kolam.

Gelembung renang yang mengalami dilatasi dan tidak dapat kembali normal disebabkan karena virus pnyebab VNN menginfeksi saraf perifer yang mengatur keseimbangan ikan dan sistem pencernaan, sehingga ikan tampak melakukan gerakan berenang vertikal yang berulang. Gerakan peristaltik usus yang tidak teratur akibat dari kerusakan sistem saraf perifer oleh infeksi VNN (Sudaryatma 2012b).
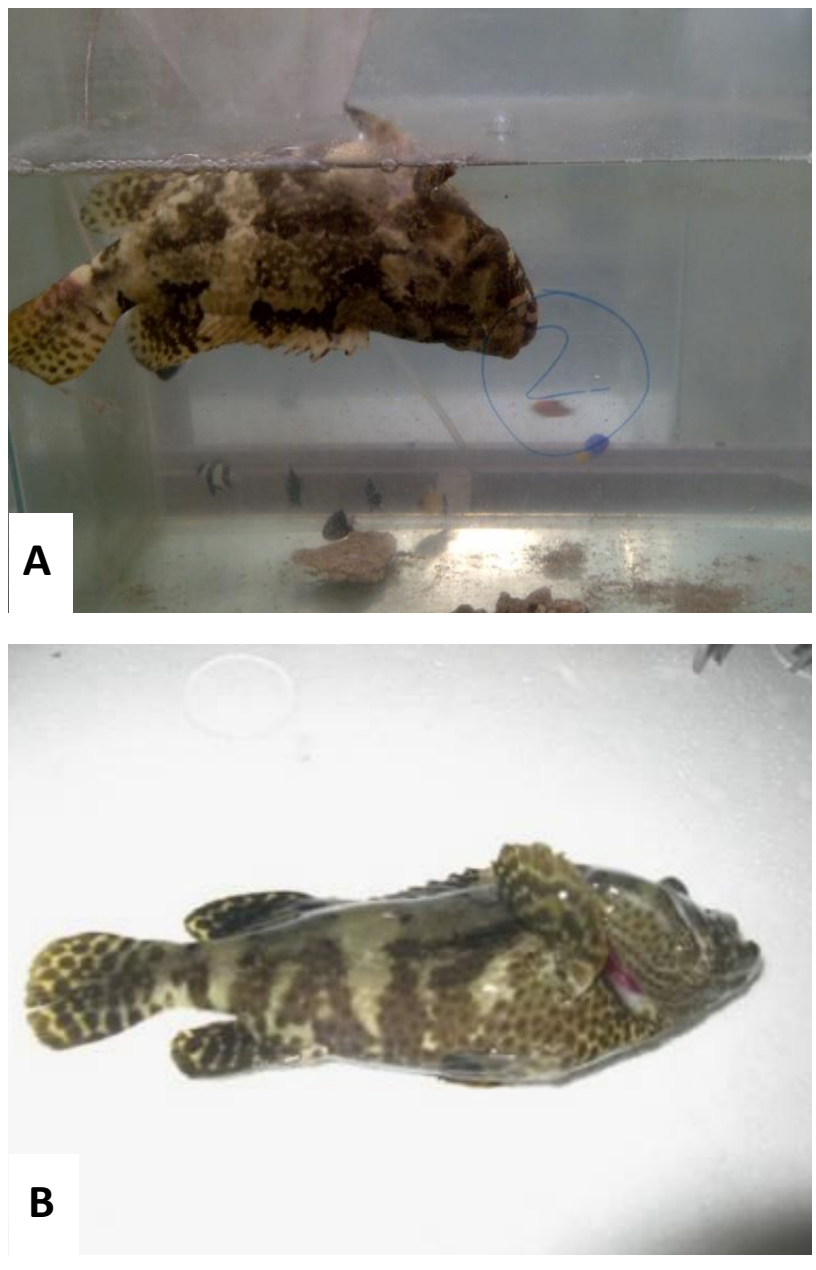

Gambar 1 Gejala klinis ikan kerapu yang berenang terbalik (A) dan tidak ada koordinasigerakan berenang 48 jam pasca infeksi virus penyebab VNN berwarna lebih gelap dan perut tampak membesar (B) 

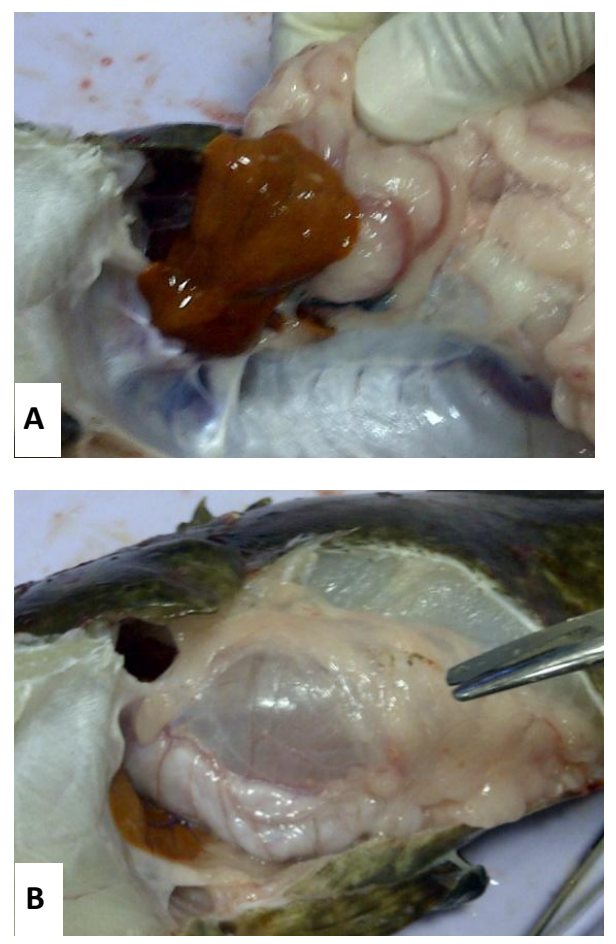

Gambar 2 Lesi patologi anatomi kerapu macan 48 jam pasca infeksi virus penyebab VNN berupa hati berwarna kekuningan (A); dan dilatasi gelembung renang dan limpa bengkak (B).

Ikan mulai sekarat setelah 57 jam pengamatan, ikan mulai berenang tidak beraturan dan terjadi penurunan gerak reflek. Banyak ikan yang mati setelah 60 jam pengamatan, hal ini menunjukkan bahwa infeksi VNN telah menyerang seluruh ikan dan menyebabkan kematian yang mendadak secara masal. Kematian ikan cenderung karena ketidakmampuan ikan untuk makan dan lemah dalam berenang sehingga ikan akan lebih cepat mati selain dari proses infeksi yang dilakukan oleh virus, keadaan ini sesuai dengan yang diungkapkan Gilda et al, (2009) bahwa kerapu yang diinfeksi VNN akan lebih cepat mati setelah 50-80 jam pasca infeksi virus penyebab VNN karena tidak dapat merespon makan yang diberikan. Nguyen et al. (1996) penularan dari ikan yang sakit membutuhkan waktu 4 hari pada infeksi alami yang dikohabitasi dalam kolam. Roza et al. (2003) dan Korsnes (2008) menyebutkan bahwa ikan akan mengalami kematian 3-5 hari pasca infeksi virus VNN yang sebelumnya menampakkan gejala klinis berenang berputar dan tidak ada refleks.

\section{Pengamatan Imunohistokimia}

Hasil imunohistokimia pada organ kerapu macan menunjukkan hasil positif VNN pada mata, otak, jantung, hati, limpa serta ginjal yang dapat

(c) 2014 Fakultas Kedokteran Hewan IPB dilihat pada Tabel 2. Organ yang terinfeksi VNN terlihat warna coklat keemasan dengan menggunakan streptavidin-biotin DAB sedangkan bila organ tidak terinfeksi akan berwarna ungu yaitu pewarna counters stain saja. Organ hati menunjukkan patologi anatomi yang berwarna kuning, limpa dan ginjal yang membengkak mungkin disebabkan oleh virus VNN setelah terjadi viremia pada ikan kerapu seperti yang dijelaskan oleh Grotmol et al. (1997) dan Grotmol et al. (1999) yaitu pembengkakan organ dapat terjadi pada beberapa organ yang mendapatkan sirkulasi darah langsung dari jantung dan pembuluh darah balik dari otak karena darah mengandung bahan genetik replikasi dari virus VNN.

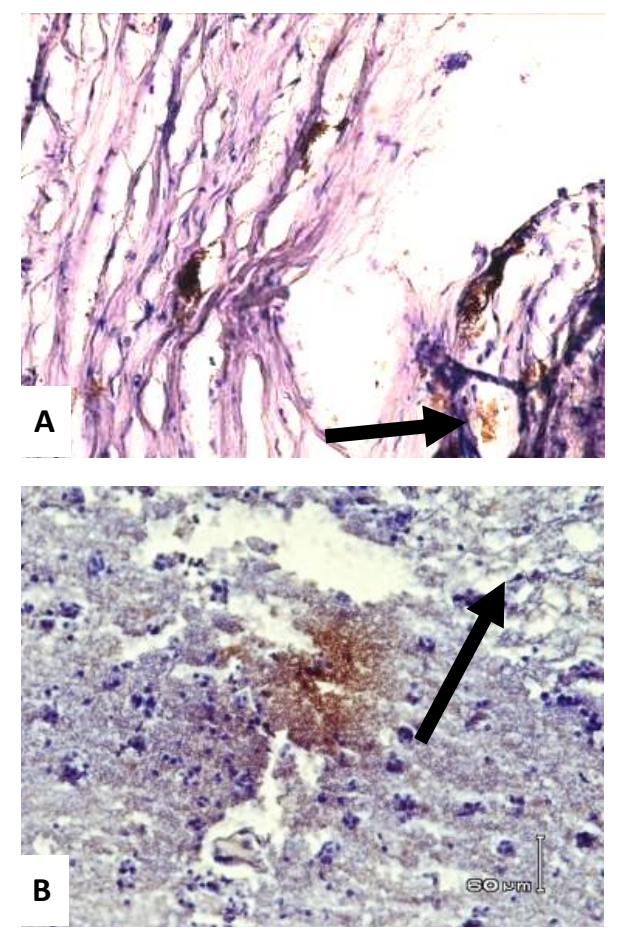

Gambar 3 A. Jaringan mata yang terinfeksi virus penyebab VNN tampak berwarna coklat keemasan dan disertai dengan vakuola pada lapisan ganglion mata (panah), B. Jaringan otak yang terinfeksi virus penyebab VNN tampak berwarna coklat keemasan dan disertai dengan adanya vakuola pada daerah cerebrum (panah) (IHC, 400X)

VNN yang diinfeksikan melalui injeksi intra muskular melakukan replikasi di otot dan masuk melalui sistem sirkulasi dan secara langsung menempel pada reseptor inang (ganglion) dengan memasukkan materi genetik dalam sel inang atau infeksi intraseluler. Sehingga target organ dari VNN dapat langsung menimbulkan perubahan lesi histopatologi vakuola dan menimbulkan gejala klinis ikan berenang berputar. Sel yang 
mengalami kerusakan (nekrosis) menyebabkan sel hancur sehingga tertinggal sebagai ruangan kosong pada jaringan otak karenaa adanya infeksi VNN intraseluler dari darah menuju otak sesuai dengan yang dikatakan Chi (2006), bahwa VNN dapat menyerang otak melalui sirkulasi darah. Dalam jaringan mata ikan kerapu yang terinfeksi VNN, kerusakan yang terjadi hampir pada seluruh jaringan mata, sehingga kerusakan yang terjadi termasuk dalam kerusakan yang parah dalam kondisi akut. Kerusakan parah terjadi pada retina mata ikan yang terinfeksi tampak pada vakuolasi di retina yang ditunjukkan pada gambar 3A. Hal itu mengakibatkan pelemahan pada syaraf mata ikan yang mengakibatkan ikan menjadi buta sehingga ikan berenang abnormal dan tidak menerima reaksi gerakan air tau makanan yang diberikan. Ikan yang tidak melakukan respon makan dan tidak melihat makanan dan akan lebih cepat mati daripada ikan yang lain.

Virus penyebab VNN dapat berada pada sel darah merah ikan kerapu (Sudaryatma et al., 2012a) yang dapat menginfeksi otot jantung disebabkan karena virus bereplikasi di darah. VNN masuk ke dalam sirkulasi melalui jantung dapat dilihat dengan adanya hasil positif berwarna coklat keemasan pada serabut otot jantung setelah 36 jam infeksi virus penyebab VNN (Gambar 4A). Pada pengamatan mikroskopis dapat dilihat adanya infiltrasi sel radang pada otot jantung yang mengindikasikan adanya reaksi peradangan akibat dari mikroorganisme yang menginfeksi otot jantung. Ikan yang diinfeksi virus penyebab VNN melalui injeksi intra muskular menyerang dengan mereplikasikan diri di sitoplasma atau di nukleus sel otot kemudian menyebar dan bereplikasi di sistem saraf perifer dimana virus akan langsung masuk ke dalam sistem saraf pusat (Sudaryatma et al. 2012b). Hal ini yang menyebabkan virus juga dapat menyebar ke seluruh organ yang bukan merupakan target organ dari virus penyebab VNN sebagai tempat bereplikasi virus. Virus menginfeksi larva dan juvenil ikan Halibut Atlantik (Hippoglossus hippoglossus) pada sel sel saraf, makrofag, limfosit, sel myocardial, pembuluh darah endotelium endokardial, usus, hati, insang, dan sirip pektoral (Grotmol et al., 1997; Grotmol et al., 1999).
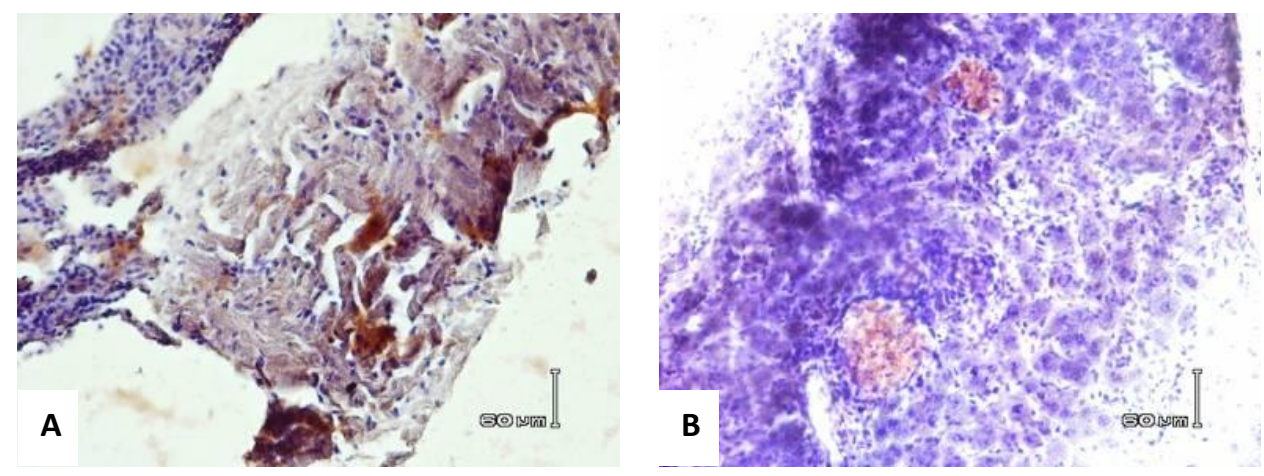

Gambar 4 A. Jaringan otot jantung yang terinfeksi virus penyebab VNN tampak berwarna coklat keemasan dan infiltrasi sel radang pada otot jantung 36 jam pasca infeksi, B. Jaringan parenkim hati yang terinfeksi virus penyebab VNN tampak berwarna coklat keemasan, degenerasi melemak, infiltrasi sel radang dan melanomakrofag 48 jam pasca infeksi (IHC, 400X).
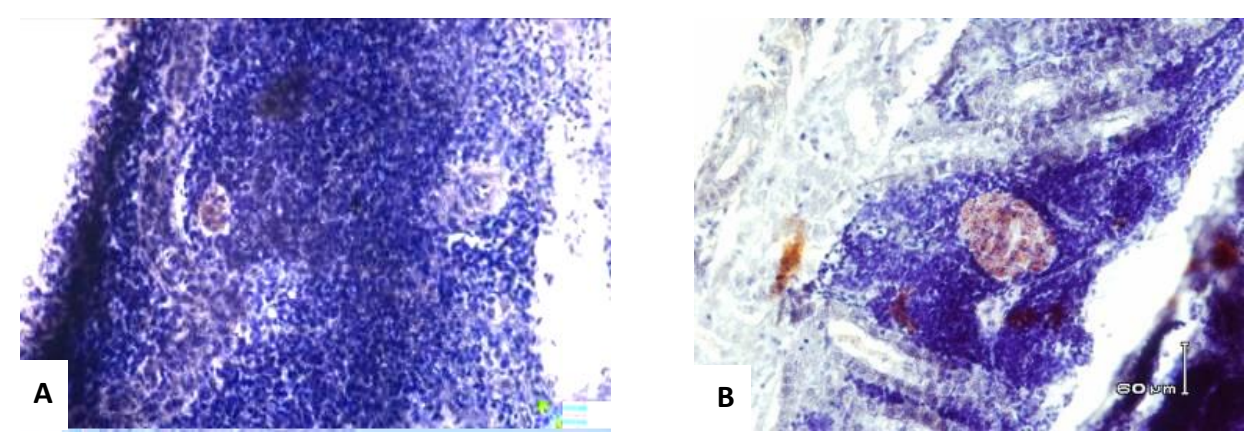

Gambar 5 A. Jaringan limpa yang terinfeksi virus penyebab VNN tampak berwarna coklat keemasan yang disertai dengan proliferasi hematopietik 48 jam pasca infeksi, B. Jaringan ginjal yang terinfeksi virus penyebab VNN tampak berwarna coklat keemasan dan adanya melanomakrofag pada interstisial tubulus ginjal 60 jam pasca infeksi (IHC, 400X). 
Keberadaan virus tersebut di organ hati dan limpa berkaitan dengan proses sirkulasi darah dan regenerasi sel darah merah yang terdapat bahan genetik replikasi virus (faktor virulensi) dan atau masih terdapat virus aktif. Pengamatan mikroskopi pada hati ditemukan adanya degenerasi melemak
Organ yang dilakukan pengamatan imunohistokimia juga diperiksa menggunakan RT-PCR yang menunjukkan bahwa kerapu yang dinjeksi virus penyebab VNN seluruhnya positif VNN dengan

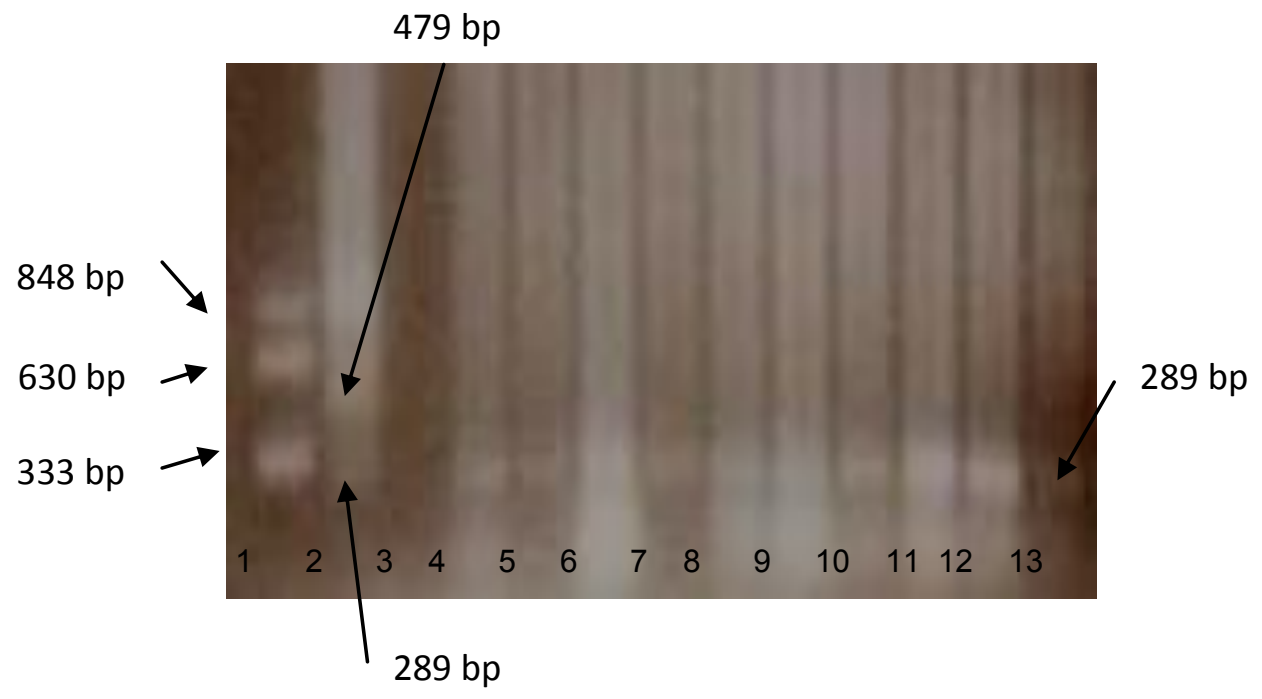

Gambar 6 Hasil uji RT-PCR kerapu macan positif VNN

Keterangan Gambar:

\author{
1. Marker ( 848 bp, 630 bp, 333 bp) \\ 2. Kontrol (+) (479 bp, 289 bp) \\ 3. Kontrol (-) VNN \\ 4. Mata $24(+)(289 \mathrm{bp})$ \\ 5. Otak $24(+)(289 \mathrm{bp})$
}

\author{
6. Jantung $36(+)$ (289 bp) \\ 7. Jantung 36(+) (289 bp) \\ 8. Hati $48(+)(289 \mathrm{bp})$ \\ 9. Hati $48(+)(289 \mathrm{bp})$
}

\begin{abstract}
10. Limpa $48(+)(289 \mathrm{bp})$
11. Limpa $48(+)(289 \mathrm{bp})$

12. Ginjal $60(+)(289 \mathrm{bp})$

13. Ginjal 6o(+) (289 bp)
\end{abstract}

pada hepatosit, warna coklat keemasan pada jaringan parenkim di hati dan terdapat infiltrasi sel radang dan melanomakrofag di tubulus hepatosit (gambar 4B) sebagai indikasi adanya infeksi virus di hati. Selain hati, ditemukan juga adanya warna coklat keemasan pada organ limpa dan ginjal yang disertai dengan adanya proliferasi hematopoietik pada limpa (gambar 5A) dan melanomakrofa. Pada interstisial tubulus di ginjal (gambar 5B). Proliferasi hematopoietik pada limpa dapat disebabkan adanya infeksi pada organ tersebut atau terjadi infeksi yang akut pada organ lain sehingga limpa memproduksi lebih sel darah yang diperlukan terutama sel radang. Pembentukan sel darah ikan setelah fase juvenil terjadi di limpa, ginjal dan sedikit di sumsum tulang belakang ikan (Aria, 2008).

\section{Hasil Uji RT-PCR}

Pengujian VNN dengan menggunakan RT-PCR bertujuan untuk konfirmasi hasil uji imunohistokimia. Hasil uji RT-PCR kerapu macan dapat dilihat pada Gambar 6. kondisi tidak terlalu parah yang ditunjukkan oleh band 289 bp dibandingkan dengan kontrol positif VNN (479 bp dan 289 bp). Kontrol positif yang digunakan adalah 200 copy pada setiap reaksi yang sesuai dengan standar kit IQ-2000. Pada sampel, hasil reaksi positif yang muncul merupakan reaksi ringan karena hanya terdapat pada band $289 \mathrm{bp}$, sedangkan reaksi sedang dan parah biasanya ditunjukkan pada band 479 bp dan 1160 bp (OIE, 2006). Metode pemeriksaan $P C R$ tidak berpengaruh terhadap munculnya virus VNN baik yang merupakan target organ ataupun bukan target organ, dikarenakan virus penyebab VNN ini menyebabkan viremia (Yuasa et al. 2001). Dari hasil uji imunohistokimia yang dikonfirmasi dengan RT-PCR menunjukkan hasil positif VNN terhadap organ dalam kerapu macan 24 sampai dengan 60 jam pasca infeksi virus penyebab VNN.

Berdasarkan hasil imunohistokimia dan konfirmasi RT-PCR dapat disimpulkan bahwa VNN dapat dideteksi keberadaannya pada semua organ dalam ikan yang mengalami viremia yaitu pada organ 
jantung, ginjal, limpa, hati, terutama pada organ mata dan otak yang merupakan organ target virus penyebab VNN dalam jangka waktu 24- 60 jam sesuai dengan tingkat keganasan dari virus penyebab VNN. Distribusi VNN yang luas pada seluruh organ tubuh menunjukkan bahwa viraemia menjadi faktor penting dalam patogenesis dan patogenitas infeksi penyakit VNN.

\section{DAFTAR PUSTAKA}

Antoro S, Sarwono HA, Sudjiharno. 2004. Biologi Pembenihan Kerapu. Balai Budidaya Laut Lampung, Direktorat Jenderal Perikanan Budidaya, Departemen Kelautan dan Perikanan. Lampung. p5-11.

Aria P, 2008. Darah ikan. http://maswira.wordpress. com. Download: 10 Maret 2009.

Chi SC. 2006. Piscine Nodavirus Infections in Asia. First International Symposium on Viral Nervous Necrosis of Fish International Conference Center. Hiroshima: November 28 to December 1, 2006.

Grotmol S, Bergh O, Totland GK. 1999. Transmission of viral encephalopathy and retinopathy (VER) to yolk-sac larvae of the atlantic halibut (Hippoglossus hippoglossus): Occurrence of nodavirus in various organs and a possible route of infection. Disease of Aquatic Organisms 36: 95-106.

Grotmol S, Totland GK, Thorud K, Hjeltnes BK. 1997. Vacuolating encephalopathy and retinopathy associated with a nodavirus-like agent: a probable cause of mass mortality of cultured larval and juvenile atlantic halibut (Hippoglossus hippoglossus). Diseases of Aquatic Organisms 29: 85-97.

Gilda D, Lio - Po, Leobert DP. 2009. Viral Disease Chapter I. http://rfdp.seafdec.org.ph. Download: February 27, 2013.

Korsnes K. 2008. Nervous Necrosis Virus (VNN) in Farmed Norwegian Fish Species. Thesis. Philosopiae Doctor (PhD), University of Bergen. Bergen: p45-60.

Koesharyani I, Zafran, Yuasa I. 1999. Deteksi Viral Nervous Necrosis (VNN) menggunakan Polymerase Chain Reaction (PCR) pada Ikan Kerapu Bebek. Pros.Sem.Nas.Pen. Dis.Tek. Budidaya Laut dan Pantai. Pusat Riset Perikanan Budidaya. Jakarta. p237-240.
Kokawa YI, Takami T, Nishizawa, Yoshimizu M. 2008. A Mixed Infection in sevenband grouper epinephelus septemfasciatus affected with viral nervous necrosis (VNN). Aquaculture 284: 41-45.

Nguyen HD, Nakai T., Muroga K. 1996. Progression of striped jack nervous necrosis virus (NNV) infection in naturally and experimentally infected striped jack pseudocaranx dentex larvae. Diseases of Aquatic Organisms 24: 99-105.

[OIE] Office International des Epizooties. 2006. Manual of diagnostic for aquatic animals.

Roza D, Johnny F dan Yuasa K. 2003. Viral diseases of grouper in Indonesia. Training on Grouper Hatchery Seed Production. Balai Besar Riset Perikanan Budidaya Laut Gondol - NACA. Gondol 1-21 Mei 2003. p12.

Sudaryatma PE, Artanti TL, Trisnasari T, Lidayana DL, Nurlita W. 2012a. Pemeriksaan viral nervous necrosis pada sampel air pemeliharaan ikan kerapu macan dengan metode imunositokimia streptavidin biotin. Jurnal Sains Veteriner 30(2): 2-12.

Sudaryatma PE, Artanti TL, Sunarsih NL, Widiarti KS, Nurhidayah SN. 2012b. Imunositokimia streptavidin biotin: deteksi dini viral nervous necrosis pada lendir ikan kerapu macan. Jurnal Sains Veteriner 30(1): 99-109.

Yoshikoshi K \& Inoue K. 1990. Viral nervous necrosis in hatchery larvae and juvenils of japanese parrotfish, oplegnathus fasciatus (Temminck \& Schelgel). Journal of Fish Disease 13: 69-77.

Yuasa K, Roza D, Koesharyani I, Johnny F and Mahardika K. 2000. General Remarks on Fish Disease Diagnosis. Textbook for the Training Course on Fish Disease diagnosis no.12. Lolitkanta-JICA. Gondol. p5-18.

Yuasa K, Koesharyani I, Roza D, Mahardika K, Johnny F dan Zafran. 2001. Manual For PCR Procedure : Rapid Diagnosis on Viral Nervous Necrosis (VNN) in Grouper no.13. Lolitkanta - JICA. Gondol. P3538. 